\title{
THE MEDIATING ROLE OF SATISFACTION TOWARD REMUNERATION SYSTEM: POS RELATED TO PERFORMANCE
}

\author{
Hunik Sri Runing Sawitri \\ hunik_sri@yahoo.co.id \\ Salamah Wahyuni \\ Anastasia Riani Suprapti \\ Desy Mayasari \\ Faculty of Economics and Business, Universitas Sebelas Maret
}

\begin{abstract}
ABSTRAK
Penelitian ini bertujuan untuk menguji bagaimana peran mediasi kepuasan atas sistem remunerasi pada pengaruh dukungan supervisor terhadap kinerja. Studi ini dilakukan pada 298 orang yang bekerja sebagai staf akademik dan staf administrasi. Sampel yang dipilih menggunakan sampel acak berstrata (stratified random sampling). Hipotesis yang diajukan dalam penelitian ini adalah 1) dukungan supervisor mempunyai pengaruh terhadap kepuasan atas sistem remunerasi, 2) kepuasan atas sistem remunerasi mempunyai pengaruh terhadap kinerja karyawan, 3) dukungan supervisor mempunyai pengaruh terhadap kinerja karyawan, dan 4) kepuasan atas sistem remunerasi memediasi pengaruh dukungan supervisor terhadap kinerja karyawan. Hasil analisis regresi menunjukkan bahwa dukungan supervisor berpengaruh positif dan signifikan terhadap kepuasan atas sistem remunerasi. Kepuasan atas sistem remunerasi berpengaruh positif dan signifikan terhadap kinerja, tetapi dukungan supervisor tidak berpengaruh signifikan terhadap kinerja. Pengujian pada efek mediasi menunjukkan bahwa kepuasan atas sistem remunerasi sepenuhnya memediasi pengaruh dukungan supervisor terhadap kinerja karyawan.
\end{abstract}

Kata kunci: dukungan supervisor, kepuasan atas sistem, remunerasi, kinerja

\begin{abstract}
This study aims to test the mediating role of satisfaction toward remuneration system on the effect of supervisor support on performance. This study is conducted to 298 people who work as academic staff and administrative staffs. The samples are selected using stratified random sampling. It is hypothesized that, 1) supervisor support affects the satisfaction toward remuneration system, 2) satisfaction toward remuneration system affects employee performance, 3) supervisor support affects employee performance, and 4) satisfaction toward remuneration system mediates the effect of supervisor support on employee performance. The result of regression analysis shows that supervisor support positively and significantly affects satisfaction toward remuneration system. Satisfaction toward remuneration system has positive and significant effect on performance, but supervisor support has no significant effect on performance. The testing on mediation effect shows that satisfaction toward remuneration system fully mediates the effect of supervisor support on employee performance.
\end{abstract}

Key words: supervisor support, satisfaction toward system, remuneration, performance

\section{INTRODUCTIONS}

In order to stimulate organizational competitiveness in public sector, Indonesian government initiated program called remuneration. The basis of the act is
Government Decree Number 23 of 2003 that amended to Government Decree Number 74 of 2014. The new amendment ensured every public sector to apply the remuneration. Indonesian public sector remuneration 
program is re-organizing of traditional payroll system into performance-based pay. Performance based-pay ensures key talent to maintain and improve their individual performance in institution (Sturman et al., 2003). Through this program, government ensures that higher performer receives higher incentives.

To date, research in pay and performance has been widely known (Judge and Klinger, 2008; Sturman et al., 2003). Only few attempts identified to assess posthoc evaluation of remuneration system in Indonesian public sector. Such researchers, however, have examined the perception of total pay satisfaction (Currall et al., 2005; Schwab and Wallace Jr, 1974; Vandenberghe and Tremblay, 2008), rather than the perception of the system procedure satisfaction. Employee understanding on payment procedure and reward information is also important to effect individual performance directly. In this study, we address the satisfaction toward remuneration system (SR) as important role to determine the job performance.

This study contributes to remuneration literature and performance in two ways. First, whereas prior researches have mainly focused in remuneration policy and total pay satisfaction, this study investigates the system procedure satisfaction of remuneration. This is important, since the procedure satisfaction is important issue, but being neglected in literature. Negligence of RS may result a poor judgment of performance based-pay (Ong et al., 2009; Petter and McLean, 2009). Well-informed employee on remuneration (e.g. the payment components transparency, ease of information access, accurate assessment method, and organization care) maintains their morale to keep performed. Additionally, the understanding of procedure helps individuals to know what to expect from their performance (Vandenberghe and Tremblay, 2008). Second, these studies also identify POS as important aspect that promotes the SR. This study probes to examine job performance as the outcome of POS and SR, putting SR as mediator, explaining how POS affects performance.

\section{LITERATURE REVIEW AND HYPO- THESIS DEVELOPMENT}

The underlying theory explaining the effects POS and SR on performance (hypothesis 2, 3, and 4) is organizational support theory (OST), in which originally developed from social exchange theory (Cropanzano and Mitchell, 2005; Kurtessis et al., 2017). The theory developed specifically to understand the psychological mechanism in effects of reciprocal mechanism. The theory assumed that POS and SR exert pressure on performance because reciprocal mechanism (Cropanzano and Mitchell, 2005; Kurtessis et al., 2017).

The tenet theory of POS on SR (H1) and POS, SR on job performance $(\mathrm{H} 2, \mathrm{H} 3, \mathrm{H} 4)$ are different, because the effects of POS to SR has no reciprocal mechanism, it is purely subjective judgment of comparing input to output (Huseman et al., 1987). Perceived organizational support assumes that an individual put strong believes to their organizations, in which their organization praises contribution and cares to well-being. The strong believe is the result of field fact from real organization intention. As the signal of organizations commitment to employee, POS also represent the evaluation of previous experience and knowledge of the organizations practices and policy. Positive perception yields higher POS, negative experience may cause absent of POS. for instance, previous experience of underpaid creates lower POS perception. POS construct is originally the extended of social exchange theory (Emerson, 1976; Levanthal, 1977).

This study is the continuation from employee attitude toward changes and the effect of transformational leadership on employee readiness. The previous study finding shows that leadership does not affect employee readiness in remuneration program (Sawitri and Wahyuni, 2018). In 
this research, follow up was done through POS. Previous study shows that perceived organizational support has a positive relationship with job satisfaction, perceived organizational support will increase job satisfaction (Eisenberger and Huntington, 1986; Settoon et al., 1996; Tremblay and Gibson, 2016) POS carry out the feeling that the organization cares on their well-being (Eisenberger and Huntington, 1986), through remuneration program in their organization. Later, believed are turned into positive feelings toward their overall reward component.

SR defined as positive or negative affects individual have from their process and output of their payment (Sturman et al., 2003). SR provides a comprehensive posthoc evaluation of reward system (Gupta, 2014). Equity theory is the basis of hypothesis one, in which explain POS may positively influence SR (Huseman et al., 1987). Individuals measures how strong organizations support. Later, employee evaluates their input (contributions and effort in performing the mundane and beyond the mundane task) and they comparing to the output (i.e. incentives, benefits). When the ratio between input and output is close, employee tends to have better satisfaction. Departing from the description above, hypothesis 1 is as follows:

Hypothesis 1 : POS has positive effect on satisfaction toward remuneration system

Growing interest in pay satisfaction (PS) has been indicated that PS has become important outcome for POS (Al-Zu'bi, 2010; Currall et al., 2005; Vandenberghe and Tremblay, 2008). Efforts to examine the concept are continuing to date. However, the PS has drawback in measuring the satisfaction, since the main focused of satisfaction was in the total amount of incentives instead of payment process. Payment process or reward procedure is important in carrying subjective judgment. Absent of procedure in payment components is indicating that subjective judgment are not capturing the real satisfaction of the payment. In addition, it may lead serious omitted problem. However, in this study, we propose satisfaction toward remuneration system in order to fill the limitation of PS.

SR originally developed from seminal word of Heneman and Schwab (1985), it referred to PS and the concept has been debatable until today. The debatable aspect was (a) structure (b) pay level, (c) pay raises, (d) administration, and (e) benefits (Heneman and Schwab, 1985). Thus, this paper captures those aspects of PS with additional adjustment in Indonesian public sector remuneration system. Later, we named the concepts as satisfaction toward remuneration system.

SR is also closely related to the job satisfaction. In organizational behavior, job satisfaction known as the important aspects of life, life satisfaction, organizational commitment, job achievement, job stress, and service quality (Porter et al., 1973). Employees play the significant role in quality of their job and retention (Thrun, 2014). Job satisfaction also becomes an important factor that contributes to job success, leads to higher performance and personal satisfaction (Peterson, 2009; Singh, 2013; Markovits et al., 2005). It predicted that satisfied employee might have better performance, which is the basic of promotion, job design, and management.

Higher performer has higher satisfaction. Thus, developed the positive feeling about system, heightened their faith that organizations put employee well-being as the priority, resulting reciprocal mechanism that high performer have to pay back in terms of individual performance. Thus, the mechanism leads employee to perform higher. While very satisfied employee may lead to perform better, the reversal is applied, lower satisfaction results under 
perform employee. Based on the descript tion, we hypothesized that:

Hypothesis 2 : Satisfaction toward remuneration system has a positive effect on performance

The concept of employee performance has been well studied. However study on the relationship between organizational support and university employee performance has not receive much attention. As previously explained, POS reflects how far employee believe that their organization appreciate their contribution and concerned with employee well-being (Francis, 2012; Stinglhamber et al., 2006). Organization, which provide high support to employee, promote emotional commitment to their employee, and employee give payback in their individual performers. In the metaanalysis of 70 studies, also shows that employee with high POS may improve their performance (Rhoades and Eisenberger, 2002).

The present of POS is important signal that organizations put higher commitment on their employee. The concept captures various employees' contributions on their items. Organization in which demonstrates work as Thus, we propose the following hypothesis.

Hypothesis 3 : POS affects performance

Perceived organizational support for creativity is defined as employee's perception on how far the organization to encourage, honors, respect, and recognize employees (Eisenberger and Stinglhamber, 2011; Singh, 2013). There is a mutually beneficial between organization and performance. Isaksen et al., (1993) state that situational outlook involves many element surroundding the context in which performance will be used and these contingencies include an individuals' perception of the predominant leadership style, reward systems, etc. Organization in which supported their employee to concentrate wholeheartedly in their work of interest, will automatically received perceived as form of supportive from their employee (Eisenberger et al., 1986; Eisenberger et al., 2001; Eisenberger and Stinglhamber, 2011). Organization provides resources, reward system, and many things that strengthen the high performer.

The result of study conducted by Guan et al. (2014) shows that the effect of organizational support on performance is mediated by employee satisfaction. Job satisfaction reflects the level of individual satisfaction toward their job. Support provided by organization may affect the need of social emotion, and indicates the availability of assistance or help, which will contribute in the overall satisfaction, including the satisfaction toward remuneration system.(Gaylord et al., 2003) state that people who evaluate an object of positive attitude (high job satisfaction) tend to be involved in parenting behavior or support, while people who evaluate an object of negative attitude (low job satisfaction) tend to be involved in the behavior that hamper or against it. Based on the description, we propose the following hypothesis.

Hypothesis 4 : Satisfaction toward remuneration system mediates the effect of organizational support on performance. 


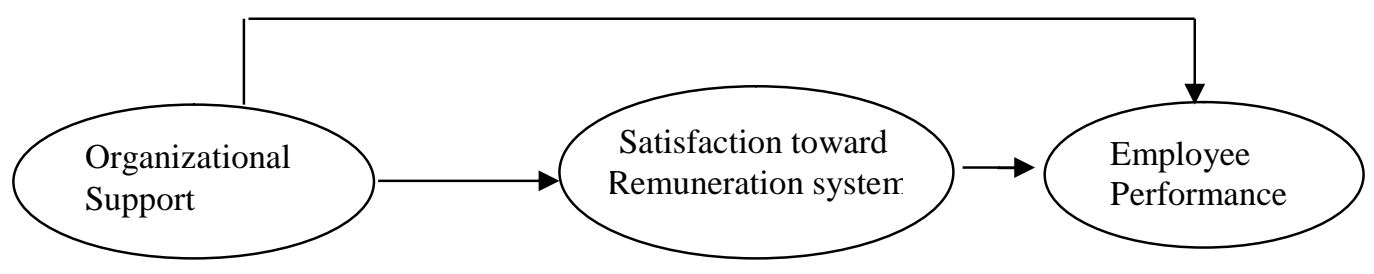

Figure 1

Research Model

Figure 1 showed the research model. Using new developed satisfaction toward remuneration system as mediation, we derived four hypotheses to capture the remuneration phenomenon. The first relationship is based on POS to satisfaction using equity theory to explain the mechanism. Further, hypothesis 2 is explain in the relationship between satisfaction to performance. Moreover, we also predict the perceived organizational support associated to performance. And finally, this study examined the mediation role of satisfaction toward remuneration system on the relationship between POS and performance.

\section{METHODOLOGY}

\section{Sample and Procedure}

The population was academic and administrative staffs in a public university in Central Java province. The university has been applied remuneration program in approximately four years when the study performed. The program in question is the implementation of remuneration system for employees, both learning staffs and administrative staffs. We employed stratified random sampling technique using the position as the basic strata. The procedure used in the data collection is as follows:

1. First, researchers contact four faculties to collect the data

2. Based on sample frame, respondents were chosen randomly based on job position.

3. Third, questionnaires distributions based on sample frame.

4. Fourth, completed questionnaire collected, with 56 percent of total question- naire. Follow-up performed for the rest of the respondents. The respond rate in second follow-up was 100 percent. However, two questionnaires remained incomplete. We excluded the incomplete questionnaire and running the analysis for the remaining 298 respondents.

\section{Operational Definition and Measurement of Variables}

Questionnaires use Likert scale 1-5. Ranging from 1 (disagree) to 5 (strongly agree) of the item to measure all variables. Exploratory factor analysis (EFA) was applied by looking at the items which will be correlated in a single factor (Hair et al., 2010). These measures are carried out considering the question of satisfaction toward remuneration system has never been tested. We entered all our survey measure items (except performance) into the analysis and, with varimax rotation, five factors with eigenvalues are greater than 1.0 emerged (Hair et al., 2010).

1. Perceived Organizational Support

Perceived Organizational support defined, as employees believe to the extent to which the organizations values their contributions and cares about their wellbeing $(\alpha=0.779)$. POS is measured using eight items from Eisenberger et al. (1997).

2. Employee Satisfaction

Employee satisfaction defined as positive or negative feeling as the result of the evaluation on procedure and total payment. $(\alpha=0.859)$. This variable 
adjusted from items developed by Hammerschmidt et al. (2016).

3. Employee Performance

Employee performance in this study is individual performance from academic and administrative staffs that are measured using the data of performance proportion (\%). This performance measurements for academic staff and administrative staffs are using different standards, but both performance measurements type are transform into percentage as the basis of payroll.

\section{Hypothesis Testing}

The hypotheses in this study are tested using regression analysis following Baron and Kenny method in testing mediation effect. We using 4 step of Baron and Kenny to measures the availability of the mediation in the model.

\section{ANALYSIS AND DISCUSSION}

Table 1 depicts the result of EFA. We performed EFA for SR and POS because SR was relatively new in measuring the payment system satisfaction. Using the cutoff 0.4 , we found tahat only POS 6 were not achieved desired score. We exclude the item
POS6 and rerun. The final result showed that all.

\section{Hypothesis Testing}

Table 2 shows the result of the regression examining the relationship between PS, POS on performance. Based on the table 2, the first hypothesis which states that supervisor support (POS) affects employee satisfaction toward remuneration system is supported. This means that higher POS lead to higher RS $(t=5.701 ; p<0.05)$.

Hypothesis 2 stated that satisfaction toward remuneration system affects performance was also supported. The result of regression analysis shows that satisfaction toward remuneration system is significantly affects performance $(t=2.302 ; p<0.05)$. The higher $S R$ created higher performer.

The regression result for the third hypothesis showed that POS did not significantly affect performance $(\mathrm{t}=$ 1.155; $\mathrm{p}>0.05$ ). Higher POS has nothing to do with higher performance. Finally, to test the mediation effect, we use Barron \& Kenny Method. The result showed that fully mediated effect was supported. Hypothesis 4 was supported

Table 1

Exploratory Factor Analysis

SR and POS

\begin{tabular}{lcc}
\hline \hline Variable & Factor 1 & Factor 2 \\
\hline ovsat1 & .828 & \\
Ovsat2 & .887 & \\
Ovsat3 & .865 & \\
Ovsat4 & .879 & \\
Ovsat5 & .875 & \\
Ovsat6 & .863 & \\
Ovsat7 & .867 & \\
Ovsat8 & .848 & \\
Ovsat9 & .882 & \\
ovsat10 & .857 & \\
ovsat11 & .872 & \\
ovsat12 & .853 & \\
\hline
\end{tabular}




\begin{tabular}{lll}
\hline ovsat13 & .697 & \\
pos1 & & .848 \\
pos2 & .825 \\
pos3 & .726 \\
pos4 & .795 \\
pos5 & .517 \\
pos7 & .480 \\
pos8 & .474 \\
\hline
\end{tabular}

Table 2

Path Analysis

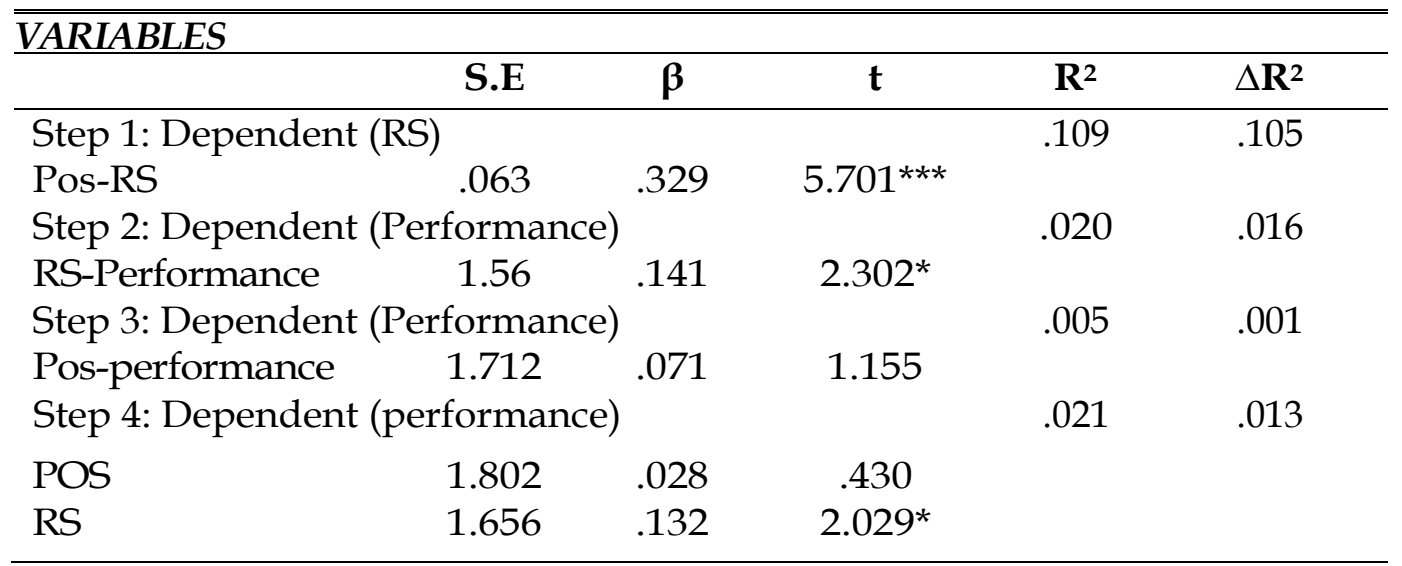

$* * *)$ significant at $\alpha \leq 0.001$

**) significant at $\alpha \leq 0.005$

*) significant at $a \leq 0.05$

\section{Discussion}

This study conducted with aims to understand the mediating role of employee satisfaction toward remuneration system on the effect of supervisor support on employee performance. There are four hypotheses: a) The effect of supervisor support on employee satisfaction, b) The effect of employee satisfaction on employee performance, c) The effect of supervisor support on employee performance, and d) employee satisfaction as the mediating variable on the effect of supervisor support on employee performance.

The analysis result shows that that supervisor support has positive and significant effect on employee satisfaction toward remuneration system. The more organizations support, the more satisfied employee with the remuneration system. This finding was in line with the previous study finding that perceived support has positive effect on employee satisfaction (Burke and Greenglass, 2001; Burke, 2003; Stamper and Johlke, 2003; ArmstrongStassen, Cameron and Horsburgh, 1996). Supervisor who encourages their subordinate to follow the changes in the system implemented by university makes employees satisfied to the system.

Satisfaction felt by employees has positive effect on performance. The result of analysis on the effect of satisfaction on performance shows positive and significant effect. This means that when employees' satisfaction toward remuneration system 
increased, their performance also improved. This result is in line with previous finding which states that satisfied employees have higher performance (Talasaz et al., 2014), and more effective and efficient performance (Martins and Proenca, 2012; Joolaee et al., 2013).

The effect of POS on performance, the analysis result shows non-significant effect. This means, supervisor support does not significantly improve employee performance (Allen et al., 2003).This result contradicts previous studies which state that supervisor support reflects employee trust toward their organization as an appreciation for their contribution (Eisenberger et al., 1986; Rhoades and Eisenberger, 2002). According to reciprocal norm, the trust is then will grow a feeling of responsibility for employees to contribute in achieving organizational objectives (Eisenberger et al., 2001). If owner provides support to their employees, according to reciprocal norm, employees tend to develop emotional commitment for their organization, so that they have high performance (Miao, 2011).

The complexity of remuneration system is allegedly become the reason as why supervisor support cannot improve subordinate performance. There is a probability that supervisor is not capable to explain and interpret the component of remuneration that can be achieved by their subordinates activities clearly, thus, supervisor support has no direct effect on performance.

However, when employees are satisfied with supervisor support, their performance are improved (Janssen, 2012). This shows the indirect effect of supervisor support on performance. In other words, employees who feel support from supervisor, will improve their performance when they are satisfied with the remuneration system.
This is why satisfaction toward remuneration system fully mediates the effect of supervisor support on performance.

\section{CONCLUSION}

The results of this study show the important role of employees' satisfaction toward remuneration system. Supervisor support alone is not capable of improving performance. Supervisor support that makes employees satisfied with the remuneration system will improve employees' performance. The importance of employee satisfaction toward remuneration system provides a signal to supervisors to understand remuneration system deeper and explain to their subordinates so that they understand the activities that will improve performance and included in the remuneration calculation.

\section{REFERENCES}

Al-Zu'bi, H. A. 2010. A Study of Relationship between Organizational Justice and Job Satisfaction. International Journal of Business and Management 5(12): 102-110.

Allen, D. G., L. M. Shore, and R. W. Griffeth. 2003. The Role of Perceived Organizational Support and Supportive Human Resource Practices in the Turnover Process. Journal of Management 29(1): 99-118.

Armstrong-Stassen, M., S. J. Cameron, and M. E. Horsburgh. 1996. The Impact of Organizational Downsizing on the Job Satisfaction of Nurses. Canadian Journal of Nursing Administration 9(4): 8-32.

Burke, R. J. and E. R. Greenglass. 2001. Hospital Restructuring and Nursing Staff Wellbeing: the Role of Perceived Hospital and Union Support. Anxiety, Stress, and Coping: An International Journal 14: 93-115.

Burke, R. J. 2003. Nursing Staff Attitudes Following Restructuring: the Role of Perceived Organizational Support, Restructuring Processes and Stressors. 
International Journal of Sociology and Social Policy 23: 129-157.

Cropanzano, R. and M. S. Mitchell. 2005. Social Exchange Theory: An Interdisciplinary Review. Journal of Management 31(6): 874-900.

Currall, S. C., A. J. Towler, T. A. Judge, and L. Kohn. 2005. Pay Satisfaction and Organizational Outcomes. Personnel Psychology 58(3): 613-640.

Eisenberger, R. and R. Huntington. 1986. Perceived Organizational Support. Journal of Applied Psychology 71(3): 500507.

Eisenberger, R., S. Armeli, B. Rexwinkel, P. D. Lynch, and L. Rhoades. 2001. Reciprocation of Perceived Organizational Support. Journal of Applied Psychology 86(1): 42-51.

Eisenberger, R., R. Huntington, S. Hutchison, and D. Sowa. 1986. Perceived Organizational Support. Journal of Applied Psychology 71(3): 500-507.

Eisenberger, R., J. Cummings, S. Armeli, and P. Lynch. 1997. Perceived Organizational Support, Discretionary Treatment, and Job Satisfaction. Journal of Applied Psychology 82(5): 812-820.

Eisenberger, R., and F. Stinglhamber. 2011. Perceived Organizational Support: Fostering Enthusiastic and Productive Employees. American Psychological Association. Washington DC.

Emerson, R. M. 1976. Social Exchange Theory. Annual Review of Sociology, 2(1976): 335-362.

Francis, C. A. 2012. The Mediating Force of "Face": Supervisor Character and Status Related to Perceived Organizational Support and Work Outcomes. Journal of Leadership and Organizational Studies 19(1): 58-67.

Gaylord, N. K., K. M. Kitzmann, and J. K. Coleman. 2003. Parents' and Children's Perceptions of Parental Behavior: Associations with Children's Psychosocial Adjustment in the Classroom. Parenting 3(1): 23-47.

Guan, X., T. Sun, Y. Hou, L. Zhao, Y. Z.
Luan, and L. H. Fan. 2014. The Relationship between Job Performance and Perceived Organizational Support in Faculty Members at Chinese Universities: A Questionnaire Survey. BMC Medical Education 14(1): 1-10.

Gupta, M. 2014. Employees' Satisfaction Towards Monetary Compensation Practices. Global Journal of Finance and Management 6(8): 975-6477.

Hair, J. F., W. C. Black, B. J. Babin, and R. E. Anderson. 2010. Multivariate Data Analysis. Vectors 5(3): 207-219.

Hammerschmidt, M., T. Falk, and B. Weijters. 2016. Channels in the Mirror: an Alignable Model for Assessing Customer Satisfaction in Concurrent Channel Systems. Journal of Service Research 19(1): 88-101.

Heneman Iii, H. G. and D. P. Schwab. 1985. Pay Satisfaction: Its Multidementional Nature and Measurement. International Journal of Psychology 20(2): 129-141.

Huseman, R. C., J. D. Hatfield, and E. W. Miles. 1987. A New Perspective on Equity Theory: the Equity Sensitivity Construct. Academy of Management Review 12(2): 222-234.

Isaksen, S. G., G. J. Puccio, and D. J. Treffinger. 1993. An Ecological Approach to Creativity Research: Profiling for Creative Problem Solving. The Journal of Creative Behavior 27(3): 149-170.

Janssen, O. 2012. Fairness Perceptions as a Moderator in the Curvilinear Relationships between Job Demands, and Job Performance and Job Satisfaction. Academy of Management Journal 44(5): 1039-1050.

Joolaee, S., H. R. Jalili, F. Rafii, F. Hajibabaee, and H. Haghani. 2013. Relationship between Moral Distress and Job Satisfaction among Nurses of Tehran University of Medical Sciences Hospitals. Journal of Nursing and Midwifery, Tehran University of Medical Sciences 18(1): 42-51.

Judge, T. A. and R. Klinger. 2008. Job 
Satisfaction: Subjective Well-Being at Work. The Science of Subjective WellBeing 393-413.

Kurtessis, J. N., R. Eisenberger, M. T. Ford, L. C. Buffardi, K. A. Stewart, and C. S. Adis. 2017. Perceived Organizational Support: A Meta-Analytic Evaluation of Organizational Support Theory. Journal of Management 43(6): 1854-1884.

Levanthal, G. S. 1977. What Should be Done with Equity Theory? New Approaches to the Study of Fairness in Social Relationships. Social Exchange Theory 152.

Martins, H. and T. Proenca. 2012. Minnesota Satisfaction Questionnaire - Psychometric Properties and Validation in a Population of Portuguese Hospital Workers. fep Working Papers (471): 1-20.

Miao, R. T. 2011. Perceived Organizational Support, Job Satisfaction, Task Performance and Organizational Citizenship Behavior in China. Journal Behavior Applied Management 12(2): 105-127.

Ong, C. S., M. Y. Day, and W. L. Hsu. 2009. The Measurement of User Satisfaction with Question Answering Systems. Information and Management 46(7): 397403.

Peterson, J. Z. 2009. Job stress, job satisfaction and intention to leave among new nurses. Job Stress, Job Satisfaction \& Intention to Leave Among New Nurses.

Petter, S., and E. R. McLean. 2009. A Metaanalytic Assessment of the DeLone and McLean IS Success Model: an Examination of IS Success at the Individual Level. Information and Management 46(3): 159-166.

Porter, L. W., R. M. Steers, P. V. Boulian, and R. Dubin. 1973. Organizational Commitment, Job Satisfaction, and Turnover among Psychiatric Technicians. Journal of Applied Psychology 59(5): 603-609.

Rhoades, L. and R. Eisenberger, R. 2002. Perceived Organizational Support: A Review of the Literature. Journal of Applied Psychology 87(4): 698-714.
Schwab, D. P. and M. J. Wallace Jr. 1974. Correlates of Employee Satisfaction with Pay. Industrial Relations 13(1): 7889.

Settoon, R. P., N. Bennett, and R. C. Liden. 1996. Social Exchange in Organizations: Perceived Organizational Support, Leader-Member Exchange, and Employee Reciprocity. Journal of Applied Psychology 81(3): 219-227.

Singh, J. K. 2013. Study of Employees' Job Satisfaction and Its. Study of Employees' Job Satisfaction and Its 1(4): 105-111.

Sawitri, H. S. R., and S. Wahyuni. 2018. Readiness to Change in the Public Sector. International Journal of Business and Society 19(1): 259-267.

Stamper, C. L. and M. C. Johlke. 2003. The Impact of Perceived Organizational Support on the Relationship between Boundary Spanner Role Stress and Work Outcomes. Journal of Management 29: 569-588.

Stinglhamber, F., D. De Cremer, and L. Mercken. 2006. Perceived Support as a Mediator of the Relationship between Justice and Trust: A Multiple Foci Approach. Group and Organization Management 31(4): 442-468.

Sturman, M. C., C. O. Trevor, J. W. Boudreau, and B. Gerhart. 2003. Is it Worth it to Win the Talent War? Evaluating the Utility of Performancebased Pay. Personnel Psychology 56(4): 997-1035.

Talasaz, Z. H., Sh. N. Saadoldin, dan M. T. Shakeri. 2014. The Relationship between Job Satisfaction and Job Performance among Midwives Working in Health-care Centers of Mashhad, Iran. Journal of Midwifery and Reproductive Health 2(3): 157-164.

Thrun, M. M. 2014. Factors Affecting Job Satisfaction and Nurse Retention. Dissertation. Walden University.

Tremblay, M., and M. Gibson. 2016. The Role of Humor in the Relationship Between Transactional Leadership Behavior, Perceived Supervisor Sup- 
140 Ekuitas: Jurnal Ekonomi dan Keuangan - Volume 2, Nomor 1, Maret 2018 : 130 - 140

port, and Citizenship Behavior. Journal of Leadership and Organizational Studies 23(1): 39-54.

Vandenberghe, C. and M. Tremblay. 2008. The Role of Pay Satisfaction and Organizational Commitment in Turnover Intentions: A Two-sample Study. Journal of Business and Psychology 22(3):
275-286.

Markovits, Y., A. J. Davis, and R. V. Dick. 2005. Organizational Commitment Profile and Job Satisfaction among Greek Private and Public Sector Employees. International Journal of Cross Cultural Management 7(1): 77-99. 